\title{
NOTE
}

\section{Coral population structure: the hidden information of colony size-frequency distributions}

\author{
Rolf P. M. Bak*, Erik H. Meesters \\ Netherlands Institute for Sea Research (NIOZ), PO Box 59, 1790 AB Den Burg, Texel, The Netherlands \\ and \\ Institute for Systematics and Population Biology, PO Box 94766, University of Amsterdam, 1090 GT Amsterdam, The Netherlands
}

\begin{abstract}
Analyses of coral colony size-frequency distributions reveal important characteristics of populations on the reef. Coral colony size-frequencies can be modelled by log normal distributions and coral populations can be described by statistics of frequency distributions such as coefficient of variation, skewness and mode. Coefficient of variation allows comparison of variation in coral populations of different mean colony size. Skewness reflects the proportion of small versus larger colonies, representing juvenile input and longevity. The mode in the size-frequency distributions represents the most frequent colony size. The mode appears indicative of a change in the relative impact of total and partial mortality in coral populations. These size-frequency variables differ significantly between coral species and, within species, between reef localities. Coral colony size-frequency diagrams provide insight into past events and have some predictive power with respect to population development. Our data demonstrate that measurement of the above-mentioned variables could be a tool to estimate the response of coral populations to the reef environment.
\end{abstract}

KEY WORDS: Coral reef survey - Colony size - Partial mortality - Modular demography

Coral reefs are possibly the most highly articulated marine systems, a characteristic which is clearly linked to the structural complexity of the key organisms: the stony corals (Scleractinia). These organisms have attracted attention since reef communities became accessible through SCUBA diving and this interest has increased because there are many coral reefs deteriorating worldwide (Buddemeier 1993, Wilkinson 1993, Ginsburg \& Glynn 1994, Birkeland 1996). Numerous studies include aspects of coral biology and ecology but some basic aspects of the population biology of coral species have hardly been touched upon. We refer to the composition of coral populations in terms of size-

·E-mail: rbak@nioz.nl frequency distributions of colonies, a pertinent aspect for corals in decline.

Earlier, a main objection to such studies was the problem of defining the individual coral colony (e.g. Stoddart \& Johannes 1978). Careful observation in situ, however, using knowledge of growth patterns and coral surface structures, overcomes this problem, at least in non-branched colonies. A second point is that corals are modular organisms and suffer partial mortality (e.g. Hughes \& Jackson 1985, Sebens 1987. Babcock 1991). Consequently, colony size was often thought not to carry much information because size was reported to be unrelated to age (but see Babcock 1991, Soong 1993). However, our studies of regeneration of coral tissue lesions (Bak 1983, Meesters \& Bak 1993) and surveys of partial mortality in the field show that the processes are more complicated. In massive coral colonies most partial mortality occurs as very small lesions that are regenerated within a few days. Also, the occurrence of partial mortality is positively related to colony size (Meesters et al. 1996, 1997). This shows that, at least in smaller colonies, size is related to age and that size distributions carry demographic information.

We were curious about what coral size-frequency distributions of coral populations in different reef settings would show. Such data are snapshots, points in time, representing stages in a dynamic process of population growth and decline. A coral population size distribution results from 2 processes: firstly, individual colony growth in size and, secondly, population dynamics in terms of numbers of colonies. For the individual colony there are 2 pertinent variables: increase/ decrease in colony surface area and colony disappearance (total mortality). Coral growth is indeterminate (Sebens 1987) and coral linear growth is approximately 
stable with age (e.g. Buddemeier \& Kinzie 1976). It follows that living coral colony surfaces, which can be modelled as e.g. semi-spheres, increase as a power function in size. Population dynamics are first order processes, i.e. modelled by exponential functions. Examples are whole colony (= total) mortality, which will control the smaller size classes in the population (Gosselin \& Qian 1997), and partial mortality (shrinkage), which is a dominant process in larger colonies (Hughes 1984). Such functions indicate that coral colony size-frequencies can be modelled by log normal distributions (Bak \& Meesters 1997).

We applied this log normal size distribution model to a data set collected at 4 sites along the fringing reefs of Curaçao (E. H. Meesters, M. Hilterman, E. Kardinaal, M. Keetman, M. de Vries, R. P. M. Bak unpubl.).
Briefly, colonies of 14 coral species (Table 1) were measured in belt transects at depths of 6 to $10 \mathrm{~m}$. We defined a colony as any autonomous, free-standing, coral skeleton with living tissue. A colony divided by partial mortality into separate patches of living tissue, but structurally still one entity, was considered to be one colony. On each colony we measured height, length and width and recorded its geometric shape(s). Total surface area of each colony was estimated using the appropriate geometric formula(s) (e.g. spherical segment, cylinder and/or part spheroid). Each colony was checked for presence of lesions/dead colony surface area and these surfaces, representing colony partial mortality, were measured. Blades of Agaricia agaricites were time consuming to measure and we calibrated measurements of length, width and height
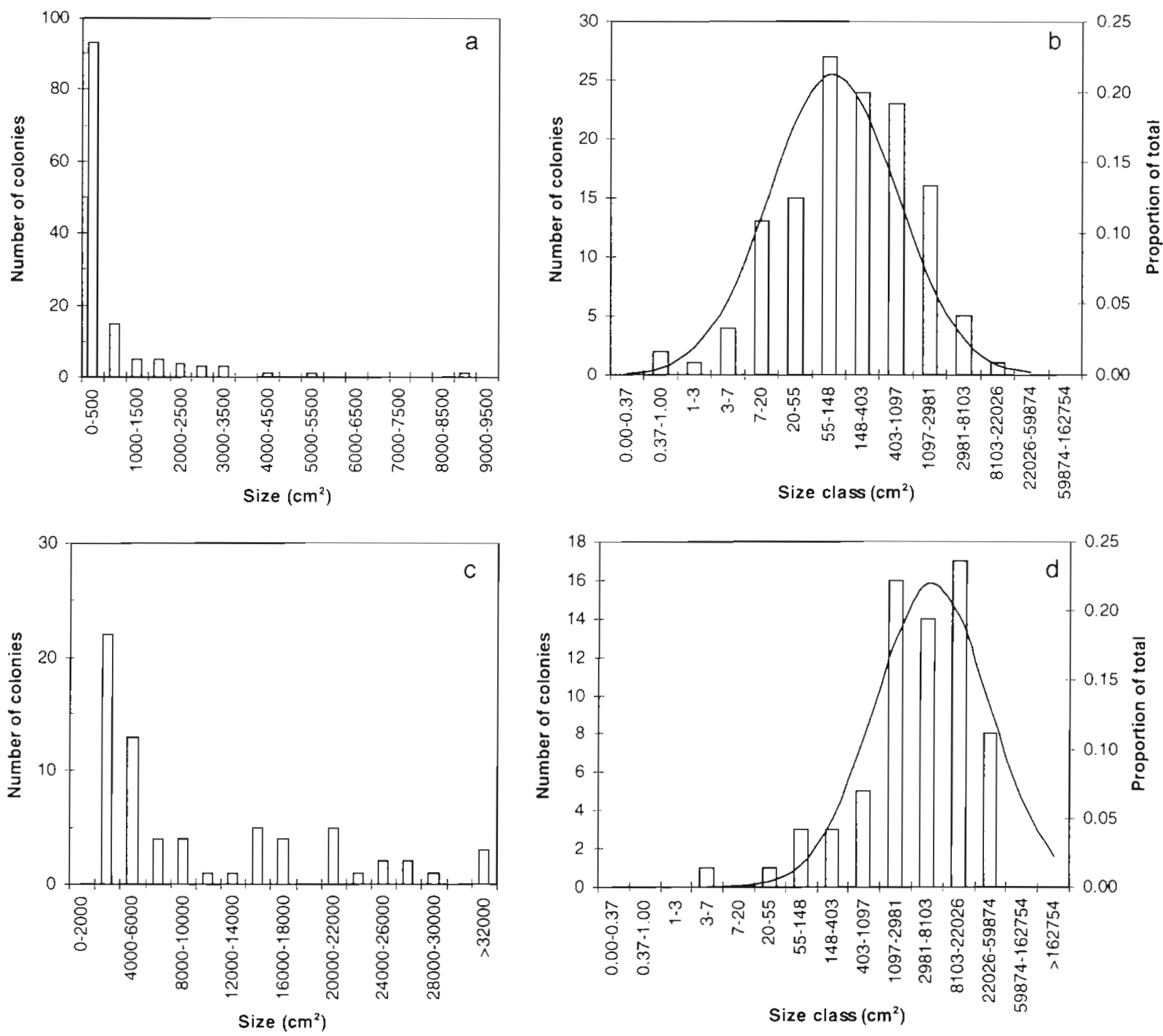

Fig. 1. Size frequency distributions on $(\mathrm{a}, \mathrm{c})$ normal and $(\mathrm{b}, \mathrm{d}) \log$ arithmic scales for $(\mathrm{a}, \mathrm{b})$ Meandrina meandrites at site 1 and (c, d) Montastraea faveolata at site 3. Descriptive statistics (normal/log): $M$. meandrites: mean 636/167, SD 1142/6.6, skewness 3.7/-0.4, coefficient of variation (V) 1.8/0.4; M. faveolata: mean 8847/3381, SD 9991/6.1, skewness 1.4/-1.1, V 1.1/0.2 
Table 1. p values of normality tests on In-transformed colony size data (Kolmogorov-Smirnov test with Lilliefors adjustment). To obtain approximately equal power in the statistical tests, we randomly selected 50 colonies if the total number sampled per site (n) was more than 50

\begin{tabular}{|c|c|c|c|c|c|c|c|c|}
\hline Species & Site 1 & $\mathrm{n}$ & Site 2 & $\mathrm{n}$ & Site 3 & $\mathrm{n}$ & Site 4 & $\mathrm{n}$ \\
\hline Agaricia agaricites & 0.289 & 87 & 0.018 & 52 & 0.000 & 313 & 0.166 & 171 \\
\hline Agaricia humilis & 0.116 & 115 & 0.212 & 116 & 0.094 & 238 & 0.180 & 132 \\
\hline Colpophyllia natans & 0.000 & 113 & 0.278 & 67 & 0.024 & 109 & 0.907 & 104 \\
\hline Dichocoenia stokesii & 0.018 & 118 & 0.656 & 109 & 0.588 & 27 & 0.334 & 20 \\
\hline Diploria labyrinthiformis & 0.282 & 37 & 0.030 & 87 & 0.174 & 55 & 0.430 & 107 \\
\hline Diploria strigosa & 0.002 & 110 & 0.009 & 114 & 0.012 & 116 & 0.511 & 57 \\
\hline Eusmilia fastigiata & 0.066 & 35 & 0.547 & 11 & 0.030 & 77 & 0.014 & 72 \\
\hline Madracis decactis & 0.047 & 101 & 0.851 & 141 & 0.863 & 149 & 0.138 & 148 \\
\hline Meandrina meandrites & 1.000 & 131 & 0.359 & 108 & 0.247 & 103 & 0.278 & 113 \\
\hline Montastraea annularis & 0.003 & 104 & 0.010 & 101 & 0.003 & 103 & 0.008 & 117 \\
\hline Montastraea faveolata & 0.149 & 52 & 0.015 & 73 & 0.059 & 68 & 0.012 & 74 \\
\hline Montastraea cavernosa & 0.561 & 118 & 0.000 & 106 & 0.149 & 114 & 0.089 & 107 \\
\hline Porites astreoides & 0.017 & 139 & 0.603 & 119 & 0.058 & 116 & 0.201 & 128 \\
\hline Siderastrea siderea & 0.020 & 128 & 0.001 & 108 & 0.233 & 101 & 0.000 & 72 \\
\hline
\end{tabular}

of total colony to colony surface area $\left(\mathrm{r}^{2}=\right.$ 0.86). For statistical analyses we used Systat 5.0 (Wilkinson 1989).

At normal arithmetic scales coral size distributions show many small colonies; numbers decrease in larger size classes down to zero in the largest, where mortality puts a limit to size (Fig. 1a, c). A more informative analysis is possible when the increase in colony size and change in numbers are analysed as a geometrical function (Fig. 1b, d). If the data are log transformed the distributions of colony size become approximately normal and a large proportion, 33 of the 56 surveyed populations (14 species, 4 sites), does not differ significantly from the model (Kolmogorov/ Smirnov, $p<0.05$; Table 1). Such distributions can be further analysed in terms of characteristics such as geometric mean, coefficient of variation, skewness and mode (Sokal \& Rohlf 1981).

The first descriptive statistic, geometric mean, differed significantly between species (Fig. 2), but in relation to sampling site (ANOVA, interaction species $x$ sites, $\left.F_{39,5755}=4.8, p<0.001\right)$. It appears that size is dependent on species identity and on environmental setting. The last point is not surprising as the different species are expected to vary in their eco/physiological responses to different environments. However, the variation between sites is small in some species and large in others, e.g. in Montastraea annularis (columnar morphotype) the difference between sites is much larger than for $M$. faveolata (massive morphotype) or M. cavernosa. The data show that the impact of the environment on variation in colony size is great in some species but not in others. In some species, e.g.

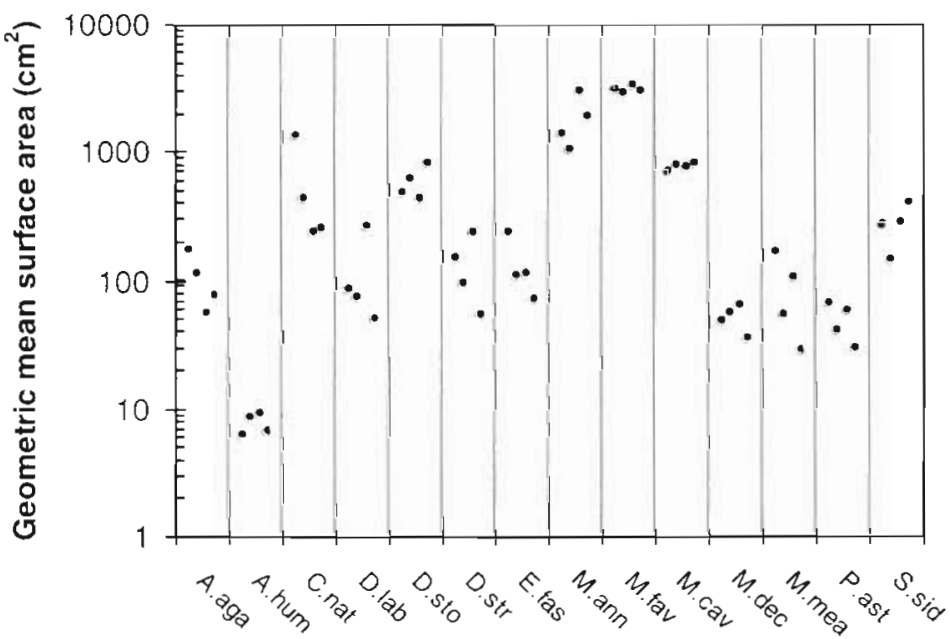

Fig. 2. Geometric mean size of 14 species at 4 reef sites along the coast of Curaçao. Species abbreviations: first letter of genus name and first 3 letters of species name. For full names see Table 1

Colpophyllia natans, the different size of different populations demonstrates that mean size can be a very localised characteristic (Fig. 2).

The most striking conclusion, however, is at the species character level. Variation in geometric mean among species was approximately 20 times that among sites and appears to be a major species characteristic. This is of interest because colony size is an interesting variable, not only indicative of age, but also related to coral reproduction (Soong \& Lang 1992). In an evolutionary perspective, larger coral size is related to lower species extinction rates (Johnson et al. 1995).

To analyze variation in colony size, we used the coefficient of variation (V), i.e. standard deviation as percentage of the mean (Sokal \& Rohlf 1981). It is a mea- 


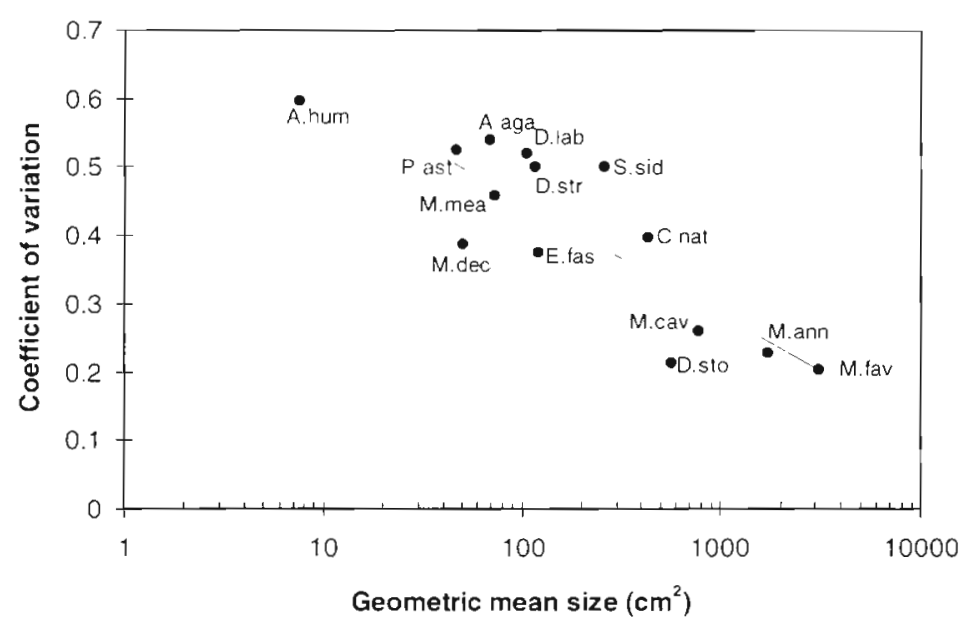

Fig. 3. Relationship between mean coefficient of variation for each species ( $\mathrm{n}=4$ sites per species) and geometric mean size. Regression: $y=$ $-0.0734 \ln (x)+0.7881 ; n=56 ; r^{2}=0.68$. Abbreviations as in Fig. 2

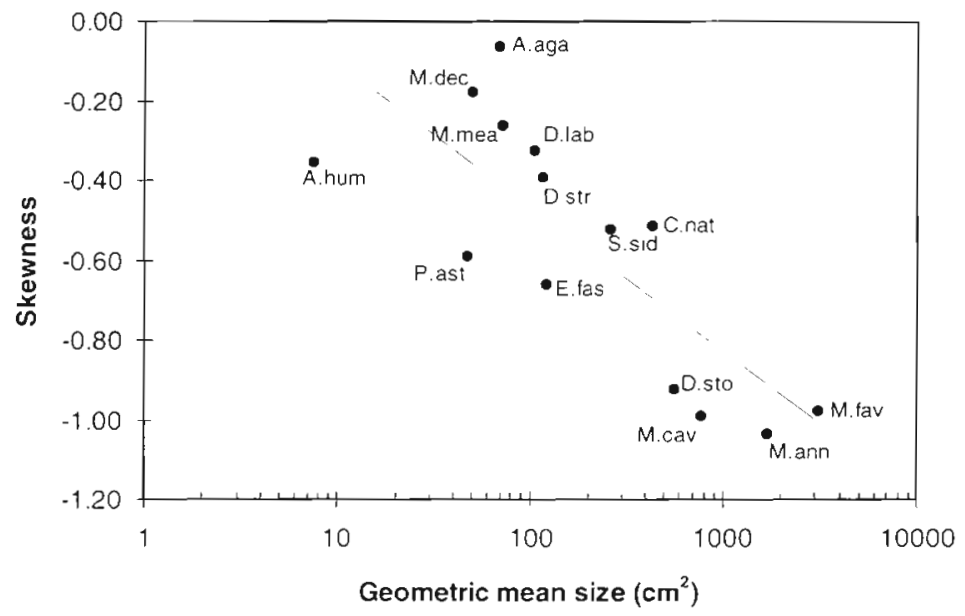

Fig. 4. Relationship between mean skewness for each species ( $n=4$ sites per species) and geometric mean size. Regression: $y=-0.1709 \ln (x)+$ $0.33 ; \mathrm{n}=56 ; \mathrm{r}^{2}=0.38$. Abbreviations as in Fig. 2

sure of the amount of variation in a data set and allows comparison between coral species/populations, irrespective of differences in mean colony size. We found standard deviation to increase in larger corals and, consequently, $\mathrm{V}$ should remain constant with increasing colony size. However, $\mathrm{V}$ changes with coral colony size (Fig. 3) and we found it to be a variable with interas well as intra-specific characteristics. $V$ differs significantly between species (ANOVA, $F_{13,42}=24.82, \mathrm{p}<$ 0.001 ) and is negatively related to the mean size of species. Size variation between colonies in populations is high in species with small colonies and low in species with large colonies. That large species have a smaller $V$ shows that variation is decreased in long living spe- cies. This suggests that $\mathrm{V}$ reflects strong temporal variation in processes such as fluctuating recruitment rates and related mortality, especially prominent in small-sized coral species.

That small colony size, and the suite of ecological processes involved with being small, is related to increased variability in colony size $(V)$ is also a trend found within species. We calculated the $\mathrm{V}$ for each of the different size classes, from small to large, within one species. Results show that within each species, $\mathrm{V}$ is largest in the smallest size class. Apparently environmental processes on reefs, relating to colony growth and mortality, cause the greatest relative variation in colony size when corals are small.

Skewness (asymmetry) is another characteristic of the coral size-frequency distributions with a high information content. It reflects the proportion of small versus large colonies. In our 56 data sets (14 species, 4 sites) 51 sets were negatively skewed (e.g. Fig. 1, Montastraea faveolata), showing that in general large colonies dominate each sizefrequency distribution. The total range in skewness was -1.68 to $+0.42\left(g_{1}\right)$ and there were significant differences in skewness between species (ANOVA, $F_{13,42}=3.035, \mathrm{p}<$ $0.001)$. This shows that the relative contribution of small and large colonies to the total population is different between species. There is also a negative relation between skewness and colony size (Fig. 4). Species distributions are, with increasing mean colony size, increasingly negatively skewed. In large species large colonies are relatively over-represented. Small-sized species have few relatively larger colonies present in populations. Such differences will have consequences for the possible range of genetic variation of sexually produced propagules and may have evolutionary significance.

The reef locations are random sites along the coast of Curaçao. Nevertheless, they vary in degree of anthropogenic coastal degradation. The size-frequency variables can be used to analyse our coral populations grouped into more and less degraded/polluted sites (Meesters et al. 1993, unpubl.). Such analyses show e.g. that skewness also varied significantly between more and less degraded reefs (ANOVA, $F_{1.12}=4.67, \mathrm{p}$ $=0.04$, branched species not included). Populations at degraded reefs tend to be more negatively skewed. This means that in such populations, irrespective of absolute colony size, there are fewer small colonies. 
Even if size were only weakly related to age, this implies that there is less recruitment to populations and that populations are aging without replenishment (see also Wittenberg \& Hunte 1992). More localities than our 4 sites must be surveyed to see if this is a rule. If it is, skewness of size-frequency distribution of massive/plating corals will tell more than coral cover about the condition, the health, of coral reefs.

The mode of the size distributions represents the most frequently occurring colony size (Fig. 5). Our data show that the mode is indicative of coral mortality processes. Firstly, it appears that partial mortality is low in small colonies and becomes an important phenomenon only after colonies reach the modal colony size (Fig. 5). Initially, in small colonies, values of partial mortality are 0.1 to $1 \%$ of the surface area of the total size class (Fig. 5). Partial mortality increases enormously in colonies larger than the mode (note log scale in Fig. 5). In the largest size classes of the populations partial mortality reached values of 30 to $50 \%$ of the total size class living surface.

Occurrence of partial mortality on coral surfaces reflects the failure of colonies to repair past damage. The similarity among species is remarkable because regeneration rates of damage vary enormously among species (Bak 1983, Meesters \& Bak 1993, Bak \& Meesters 1997), e.g. in our example (Fig. 5) Meandrina meandrites is a very rapidly regenerating species, compared with Agaricia agaricites. The data suggest that many other factors, such as growth form, are involved and steer the regeneration process to such similar results in different species.

Secondly, colonies reaching the size of the modal size class are usually still quite small. In our example (Fig. 5) Agaricia agaricites is a submassive blade (radius about $2 \mathrm{~cm}$ ), Meandrina meandrites a hemisphere (radius about $4 \mathrm{~cm}$ ). That partial mortality is noticeable only in populations larger than this small size suggests that the factors which cause partial mortality in larger colonies cause total mortality in colonies smaller than the mode. Total mortality is reported to be relatively important in smaller colonies (Soong 1993, Meesters et al. 1997). Our hypothesis is that the mode of the colony size-frequency of coral populations is the turning point. This is the threshold size where total mortality becomes less important than partial mortality. If this is true, than the first part of the curve of the size-frequency distribution, up to the mode, represents not only colony size but also the age structure of the population.

It appears that the statistics of coral colony size-frequency distributions are useful tools to analyse rele-

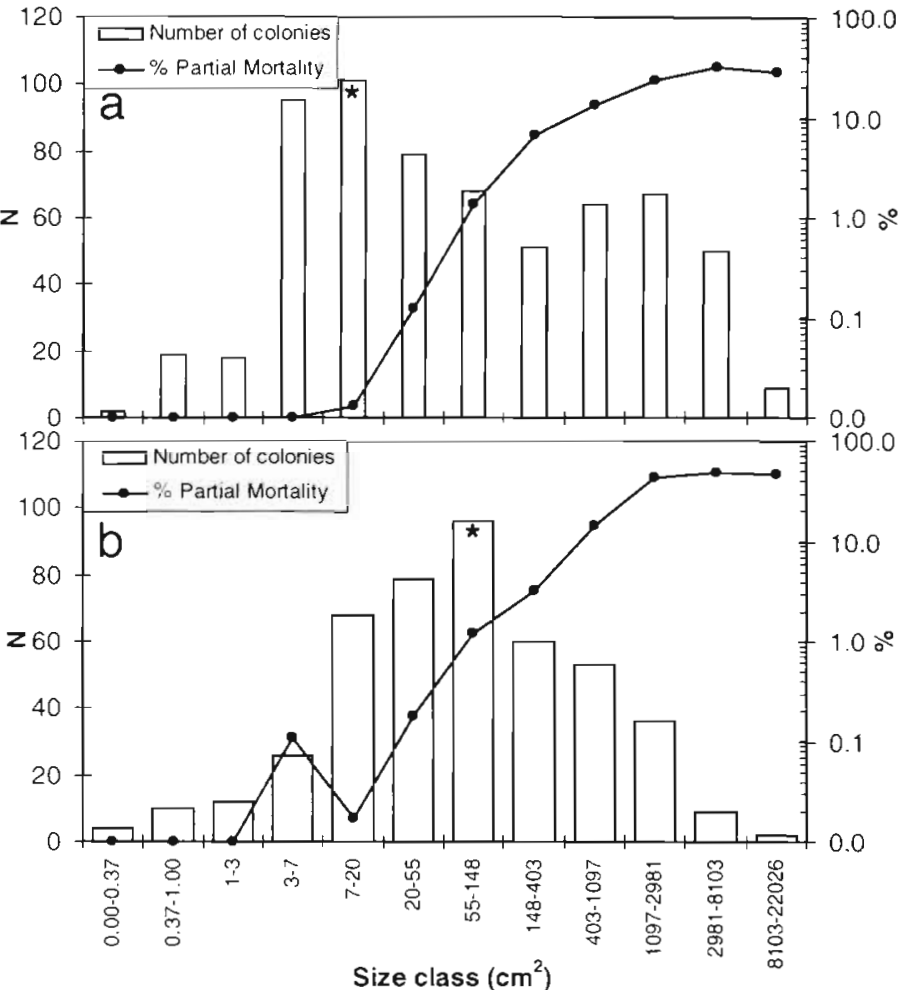

Fig. 5. Size-frequency distributions and percentage partial mortality per colony (mean for each size class) for (a) Agaricia agaricites and

(b) Meandrina meandrites. Modal size class indicated by asterisk

vant characteristics of coral populations. Partial mortality, an inherent characteristic of modular scleractinian corals, does not distort our size-frequency distributions beyond interpretation. Its effects can be recognized, the magnitude can be measured and a possible threshold value, after which it becomes important, can be established. It is necessary to realize that our species were submassive/massive (11), sturdy branched (2) and upright blade (1) colony shapes. In other growth forms, e.g. horizontally plating morphologies, partial mortality may have different impact (Hughes \& Jackson 1980).

Apart from their intrinsic interest, coral population size-frequency statistics can become important tools in studying declining coral reefs (e.g. in programs such as Reef Check and the Global Coral Reef Monitoring Network). The most common variables measured in reef coral surveys are usually coral cover or colony diameter. The problems in interpreting such data in terms of 'reef condition' or 'reef health' are insurmountable because the earlier base data needed for interpretation are generally not available (Ginsburg \& Glynn 1994). The variables we present include an understandable record of prior history of a coral population. They show the relation of partial mortality with coral colony size. In addition, variables such as skewness differed 
between deteriorating and other reefs. We conclude that surveys including size-frequency distributions and analyses of coefficient of variation, skewness and mode could be used to evaluate conditions and changes in coral communities.

Acknowledgements. We are grateful to the staff of Carmabi for facilities and logistical support and to Maartje Hilterman, Edwin Kardinaal, Machiel Keetman, Martijn de Vries, Ineke Wesseling and many other students for their interest and help in surveying the Curaçao reets. We thank Dr Charles Birkeland for his comments on the ms. This is NIOZ contribution 3214

\section{LITERATURE CITED}

Babcock RC (1991) Comparative demography of three species of scleractinian corals using age- and size-dependent classifications. Ecol Monogr 61:225-244

Bak RPM (1983) Neoplasia, regeneration and growth in the reefbuilding coral Acropora palmata. Mar Biol 77:221-227

Bak RPM, Meesters EH (1997) Coral diversity, populations and ecosystem functioning. Proc 6th Int Symp Coel Biol, Nat Nat-Hist Mus, Leiden, p 27-38

Birkeland C (1996) Life and death of coral reefs. Chapman \& Hall, New York

Buddemeier RW (1993) Corals, climate and conservation. Proc 7 th Int Coral Reef Symp 1:3-10

Buddemeier RW, Kinzie RA (1976) Coral growth. Oceanogr Mar Biol Ann Rev 14:183-225

Ginsburg RN, Glynn PW (1994) Summary of the Colloquium and Forum on Global Aspects of Coral Reefs: Health, Hazards and History. In Ginsburg RN (ed) Proc Colloquium Global Aspects of Coral Reefs. Rosenstiel School of Marine and Atmospheric Science, University of Miami, $p$ i-ix

Gosselin LA, Qian PY (1997) Juvenile mortality in benthic marine invertebrates. Mar Ecol Prog Ser 146:265-282

Hughes TP (1984) Population dynamics based on individual size rather than age: a general model with a coral reef

Editorial responsibility: Otto Kinne (Editor), Oldendorf/Luhe, Germany example. Am Nat 1.23:778-795

Hughes TP, Jackson JBC (1980) Do corals lie about thelr age? Some demographic consequences of partal mortality, fission and fusion. Science 209:713-714

Hughes TP, Jackson JBC (1985) Population dynamics and life histories of foliaceous corals. Ecol Monogr 55:141-166

Johnson K, Budd A, Stemann TA (1995) Extinction selectivity and ecology of Neogene Caribbean reef corals. Paleobiol $21: 52-73$

Meesters EH, Bak RPM (1993) Effects of coral bleaching on tissue regeneration and colony survival. Mar Ecol Prog Ser 96:189-198

Meesters EH, Bos A, Gast GJ (1993) Effects of sedimentation and lesion position on coral tissue regeneration. Proc 7 th Int Coral Reef Symp 2:681-688

Meesters EH, Wesseling I, Bak RPM (1996) Partial mortality in three species of reef-building corals and the relation with colony morphology. Bull Mar Sci 58:838-852

Meesters EH, Wesseling I, Bak RPM (1997) Coral colony tissue damage in six species of reef-building corals: partial mortality in relation with depth and surface area. J Sea Res 37:131-144

Sebens KP (1987) The ecology of indeterminate growth in animals. Annu Rev Ecol Syst 18:371-407

Sokal RR, Rohlf FJ (1981) Biometry, 2nd edn. WH Freeman and Company, New York

Soong K (1993) Colony size as a species character in massive reef corals. Coral Reefs 12:77-83

Soong K, Lang JC (1992) Reproductive integration in reef corals. Biol Bull (Woods Hole) 183:418-431

Stoddart DR, Johannes RE (1978) Coral reef research methods. UNESCO, Paris

Wilkinson CR (1993) Coral reefs of the world are facing widespread devastation: can we prevent this through sustainable management practices? Proc 7 th Int Coral Reef Symp $1: 11-21$

Wilkinson I (1989) Systat, the system for statistics. Systat, Evanston, IL

Wittenberg M, Hunte W (1992) Effects of eutrophication and sedimentation on juvenile corals. I. Abundance, mortality and community structure. Mar Biol 112:131-138

Submitted: September 15, 1997; Accepted: December 17, 1997 Proofs received from author(s): February 2, 1998 